\title{
Proces konstytuowania Unii Bankowej. Geneza, podstawy prawne, cele i zasady działania
}

\section{Uwagi wstępne}

Przedmiotem analizy jest Unia Bankowa, czyli nowa struktura organizacyjna Unii Gospodarczej i Walutowej. Unia Bankowa wraz z Unią Fiskalną oraz tzw. zintegrowanymi ramami polityki gospodarczej to trzy istotne zmiany ustrojowe w strefie euro, które zostały zaproponowane w grudniu 2012 r. przez Radę Europejską w oparciu o raport Hermana Van Rompuy'a. W znaczeniu doraźnym Unia Bankowa jest także rozumiana jako instrument walki ze skutkami kryzysu zadłużeniowego w strefie euro. Unia Bankowa ma uzyskać pełną zdolność do działania od 1 stycznia 2016 r. W pierwszej części artykułu przedstawione zostały: proces legislacyjny i podstawy prawne, w oparciu o które przebiegają prace nad ustanowieniem Unii Bankowej. W części drugiej omówiono cele i zasady działania Unii Bankowej, zaś w części trzeciej wynikające $\mathrm{z}$ tego nowe uprawnienia Europejskiego Banku Centralnego, Parlamentu Europejskiego, Komisji Europejskiej, Trybunału Obrachunkowego, Rady Unii Europejskiej oraz parlamentów narodowych.

\section{Geneza}

Przełomowe znaczenie w walce $\mathrm{z}$ kryzysem finansowym, który na przełomie lat 2010/2011 przekształcił się w kryzys zadłużeniowy (Komisja Europejska, Notatka prasowa z 15 kwietnia 2014) miało posiedzenie Rady Europejskiej w dniach 14-15 grudnia 2012 r. Przyjęty został wówczas raport Hermana Van Rompuy’a, przygotowany wspólnie z przewodniczącymi Komisji Europejskiej i Eurogrupy oraz prezesem EBC zatytulowany W kierunku faktycznej Unii Gospodarczej i Walutowej (Rada Europejska, Sprawozdanie końcowe z 5 grudnia 2012 r.).

$\mathrm{Na}$ jego podstawie Rada Europejska uchwaliła konkluzje określające zasadnicze kierunki reformy ustrojowej strefy euro. Miała ona polegać na ustanowieniu tam trzech bardzo istotnych zmian: po pierwsze, zintegrowanych ram finansowych (Unia Bankowa); po drugie, zintegrowanych ram budżetowych (Unia Fiskalna); po trzecie, zintegrowanych ram polityki gospodarczej (mechanizm ds. koordynacji ex ante głównych reform gospodarczych oraz mechanizm koordynacji ex ante i konwergencji polityk strukturalnych w oparciu o umowy reformatorskie) $)^{1}$. Wspomniane zmiany ustrojowe

1 W pełni zintegrowane ramy budżetowe winny powstać w kilku etapach. W perspektywie krótkoterminowej należałoby zakończyć proces implementacji sześciopaku, paktu fiskalnego i dwupaku, 
winny uzyskać legitymizację w postaci rozszerzenia kompetencji Europejskiego Banku Centralnego, Parlamentu Europejskiego, Komisji Europejskiej, Trybunału Obrachunkowego, Rady Unii Europejskiej i parlamentów narodowych w strefie euro (Posiedzenie Rady Europejskiej z 13-14 grudnia 2012 r.).

Implementacja postanowień raportu Van Rompuy'a objęła w pierwszej kolejności działania na rzecz ukonstytuowania Unii Bankowej. Miałaby się ona opierać na trzech filarach: jednolitym mechanizmie nadzorczym; jednolitym mechanizmie restrukturyzacji i uporządkowanej likwidacji, a także powiązanych ze sobą mechanizmach finansowania (wspólnych dla całego rynku wewnętrznego), czyli jednolitym funduszu restrukturyzacji i uporządkowanej likwidacji, systemie gwarantowania depozytów oraz wspólnym mechanizmie ochronnym (linia kredytowa).

Podczas posiedzenia Rady Europejskiej w dniach 14-15 marca 2013 r. dokonano podsumowania prac nad pogłębieniem Unii Gospodarczej i Walutowej oraz uznano, że priorytetem będzie na razie zakończenie procesu ustawodawczego w sprawie ustanowienia Jednolitego Mechanizmu Nadzorczego (Posiedzenie Rady Europejskiej z 14-15 marca 2013 r.). Natomiast w czasie posiedzenia Rady Europejskiej w dniach 27-28 czerwca 2013 r. potwierdzono, że należy dokończyć proces konstytuowania Unii Bankowej, gdyż ma to podstawowe znaczenie dla zapewnienia stabilności finansowej. W konkluzjach podkreślono także, że w pełni skuteczny Jednolity Mechanizm Nadzorczy wymaga ustanowienia Jednolitego Mechanizmu Restrukturyzacji i Uporządkowanej Likwidacji (Posiedzenie Rady Europejskiej z 27-28 czerwca 2013 r.). Z kolei podczas posiedzenia w dniach 20-21 marca 2014 r. Rada Europejska wezwała Parlament Europejski i Radę Unii Europejskiej do jak najszybszego uchwalenia rozporządzenia w sprawie ustanowienia Jednolitego Mechanizmu Restrukturyzacji i Uporządkowanej Likwidacji, a także zaapelowała do rządów państw członkowskich strefy euro o zakończenie negocjacji nad umową międzyrządową w sprawie utworzenia Jednolitego Funduszu Restrukturyzacji i Uporządkowanej Likwidacji (Posiedzenie Rady Europejskiej z 20-21 marca 2014 r.).

których celem byłaby koordynacja ex ante rocznych budżetów państw członkowskich strefy euro. W ślad za tym powinno dojść do uzgodnienia pułapu rocznego salda budżetowego i długu publicznego dla państw strefy euro, co w perspektywie średnioterminowej stworzyłoby uwarunkowania dla emisji wspólnego długu bez odwoływania się do uwspólnienia długu państwowego. Emisja długu publicznego ponad wspólnie ustalony pułap musiałaby być uzasadniona i uprzednio zatwierdzona przez instytucje Unii Europejskiej. Natomiast w perspektywie długoterminowej należałoby ustanowić odrębny budżet strefy euro oraz organ skarbowy o wyraźnie zdefiniowanych obowiązkach. Wszystkie wspomniane wyżej reformy miałyby doprowadzić do utworzenia Unii Fiskalnej. Zintegrowane ramy polityki gospodarczej winny stanowić dopełnienie Unii Bankowej i Unii Fiskalnej. W perspektywie krótkoterminowej winno dojść do zakończenia procesu tworzenia jednolitego rynku. Opierając się na europejskim semestrze i pakcie euro plus, należałoby uczynić ramy koordynowania głównych reform polityki gospodarczej bardziej niż dotą możliwymi do wyegzekwowania. $\mathrm{W}$ związku $\mathrm{z}$ tym należałoby ustanowić mechanizm koordynacji ex ante głównych reform polityki gospodarczej zgodnie z art. 11 paktu fiskalnego, a także mechanizm koordynacji ex ante i konwergencji polityk strukturalnych. W ramach tego ostatniego mechanizmu zainteresowane państwa członkowskie strefy euro zawierałyby z instytucjami unijnymi umowy reformatorskie, w których zobowiązywałyby się do wzmocnienia konkurencyjności swoich gospodarek, przyspieszenia wzrostu gospodarczego oraz obniżenia bezrobocia, por. Rada Europejska, Sprawozdanie końcowe z 5 grudnia 2012 r. Posiedzenie Rady Europejskiej z 13-14 grudnia 2012 r. 


\section{Podstawy prawne}

Podstawę prawną dla utworzenia Unii Bankowej stanowią przepisy prawa pierwotnego i pochodnego Unii Europejskiej. W dziedzinie prawa pierwotnego są to postanowienia Traktatu o funkcjonowaniu Unii Europejskiej (TFUE). Art. 114 ust. 1 TFUE przewiduje możliwość przyjmowania przez Parlament Europejski i Radę Unii Europejskiej w zwykłej procedurze ustawodawczej środków służących harmonizacji (zbliżeniu) przepisów ustawowych, wykonawczych i administracyjnych państw członkowskich, mających na celu ustanowienie i funkcjonowanie rynku wewnętrznego. Art. 127 ust. 6 TFUE stanowi, że Rada Unii Europejskiej, działając w ramach specjalnej procedury ustawodawczej, może uchwalić rozporządzenie, w którym powierzy Europejskiemu Bankowi Centralnemu szczególne zadania dotyczące polityk w dziedzinie nadzoru ostrożnościowego nad instytucjami kredytowymi i innymi instytucjami finansowymi, z wyjątkiem instytucji ubezpieczeniowych. Rada stanowi przy tym jednomyślnie i po konsultacji z Parlamentem Europejskim oraz Europejskim Bankiem Centralnym. Natomiast art. 53 ust. 1 TFUE upoważnia Parlament Europejski i Radę Unii Europejskiej m.in. do uchwalania w ramach zwykłej procedury ustawodawczej dyrektyw służących koordynacji przepisów ustawowych, wykonawczych i administracyjnych państw członkowskich, dotyczących podejmowania i wykonywania działalności prowadzonej na własny rachunek (Traktat z Lizbony, Dz. Urz. UE C, 2008, nr 115).

Jeśli chodzi o przepisy prawa pochodnego, to były one w ostatnich latach na bieżąco uchwalane na podstawie wspomnianych wyżej postanowień TFUE. Już w drugiej połowie roku 2012 Komisja Europejska w dwóch komunikatach przedłożyła harmonogram prac legislacyjnych w tej sprawie (Komunikat Komisji z 12 września 2012 r.; Komisja Europejska, Komunikat z 30 listopada 2012 r.). Łącznie w latach 2012-2014 przedstawiła ona kilkanaście wniosków legislacyjnych, obejmujących wszystkich uczestników rynku finansowego i wszystkie produkty finansowe (Komisja Europejska, Notatka z 15 kwietnia 2014 r.).

\section{III.1. Pierwszy filar}

Podstawy prawne dla pierwszego filaru Unii Bankowej stanowią m.in. 4 rozporządzenia, 1 dyrektywa oraz 1 porozumienie międzyinstytucjonalne. 26 czerwca 2013 r. Parlament Europejski i Rada Unii Europejskiej uchwaliły dwa akty prawne dotyczące wymogów kapitałowych dla banków. Pierwszym z nich było rozporządzenie w sprawie wymogów oszczędnościowych dla instytucji kredytowych i firm inwestycyjnych, zmieniające rozporządzenie (UE) nr 648/2012, zaś drugim była dyrektywa dotycząca warunków dopuszczających instytucje kredytowe do działalności oraz nadzoru ostrożnościowego nad instytucjami kredytowymi i firmami inwestycyjnymi, zmieniająca dyrektywę 2002/87/WE oraz uchylająca dyrektywy 2006/48/WE i 2006/49/WE (Rozporządzenie PE i RUE z dnia 26 czerwca 2013 r. Dz. Urz. UE L, 2013, 176, s. 1-337. Dyrektywa PE i RUE z dnia 26 czerwca 2013 r., Dz. Urz. UE L, 2013, nr 176, s. 338-436). W następnych miesiącach uchwalone zostały 3 dalsze rozporządzenia i 1 porozumienie międzyinstytucjonalne. I tak, 15 października 2013 r. Rada Unii Europejskiej uchwaliła 
rozporządzenie, na mocy którego $\mathrm{EBC}$ powierzone zostały nowe zadania w zakresie nadzoru ostrożnościowego nad instytucjami kredytowymi. Uprawnienia te miały być realizowane $\mathrm{w}$ ramach nowo powołanego na podstawie analizowanego rozporządzenia Jednolitego Mechanizmu Nadzorczego (Single Supervisory Mechanism - SSM) (Rozporządzenie RUE z dnia 15 października 2013 r., Dz. Urz. UE L,2013, nr 287, s. 63-89). 22 października 2013 r. Parlament Europejski i Rada Unii Europejskiej uchwaliły rozporządzenie w sprawie zmiany rozporządzenia ustanawiającego Europejski Urząd Nadzoru Bankowego (UE) nr 1093/2010 w związku z planowanym ustanowieniem Jednolitego Mechanizmu Nadzorczego (Rozporządzenie PE i RUE z dnia 22 października 2013 r. Dz. Urz. UE L, 2013, nr 287, s. 5-10). Z kolei 6 listopada 2013 r. Parlament Europejski i Europejski Bank Centralny zawarły porozumienie międzyinstytucjonalne w sprawie sprawowania nadzoru nad wykonywaniem zadań powierzonych EBC w ramach Jednolitego Mechanizmu Nadzorczego (Porozumienie międzyinstytucjonalne mi?dzy PE a EBC z dnia 6 listopada 2013 r., Dz. Urz. UE L, 2013, nr 320, s. 1-6). Natomiast 16 kwietnia 2014 r. Europejski Bank Centralny uchwalił rozporządzenie określające zasady współpracy pomiędzy nim a właściwymi organami krajowymi w ramach Jednolitego Mechanizmu Nadzorczego (Rozporządzenie EBC z dnia 16 kwietnia 2014 r., EBC 2014/17, s. 1-88).

\section{III.2. Drugi filar}

15 maja 2014 r. Parlament Europejski i Rada Unii Europejskiej przyjęły dyrektywę ustanawiającą ramowe uwarunkowania dla działań naprawczych oraz restrukturyzacji i uporządkowanej likwidacji instytucji kredytowych i firm inwestycyjnych (tzw. dyrektywa BRRD). Dyrektywa stanowi zbiór przepisów dla procesu restrukturyzacji i uporządkowanej likwidacji banków na całym rynku wewnętrznym Unii Europejskiej. Ma ona wspierać Jednolity Mechanizm Restrukturyzacji i Uporządkowanej Likwidacji (Dyrektywa PE i RUE z dnia 15 maja 2014 r., Dz. Urz. UE L, 2014, nr 173, s. 190-348). Dokładnie 2 miesiące później, 15 lipca 2014 r. Parlament Europejski i Rada Unii Europejskiej uchwaliły rozporządzenie ustanawiające jednolite zasady oraz jednolitą procedurę restrukturyzacji i uporządkowanej likwidacji instytucji kredytowych i niektórych firm inwestycyjnych w ramach Jednolitego Mechanizmu Restrukturyzacji i Uporządkowanej Likwidacji oraz Jednolitego Funduszu Restrukturyzacji i Uporządkowanej Likwidacji. Rozporządzenie ustanawia 3 nowe instrumenty: Jednolity Mechanizm Restrukturyzacji i Uporządkowanej Likwidacji; jednolite zasady oraz jednolitą procedurę restrukturyzacji i uporządkowanej likwidacji; Jednolitą Radę ds. Restrukturyzacji i Uporządkowanej Likwidacji, a także Jednolity Fundusz Restrukturyzacji i Uporządkowanej Likwidacji (Rozporządzenie PE i RUE z dnia 15 lipca 2014 r., Dz. Urz. UE L, 2014, nr 225, s. 1-90). Jednolity Mechanizm Restrukturyzacji i Uporządkowanej Likwidacji (Single Resolution Mechanism - SRM) będzie wykorzystywany w państwach objętych Jednolitym Mechanizmem Nadzorczym. Natomiast w pozostałych państwach członkowskich Unii Europejskiej będą stosowane przepisy dyrektywy z 15 maja 2014 r., która przewiduje działania w oparciu o krajowe organy restrukturyzacji i uporządkowanej likwidacji. 


\section{III.3. Trzeci filar}

O ile proces ustawodawczy dotyczący ustanowienia pierwszego i drugiego filaru Unii Bankowej został już zakończony, o tyle proces legislacyjny odnoszący się do trzeciego filaru w dalszym ciagu trwa. Wprawdzie dobiegły już końca prace nad dyrektywą ustanawiającą system gwarantowania depozytów, którą 16 kwietnia 2014 r. uchwaliły Parlament Europejski i Rada Unii Europejskiej (Dyrektywa PE i RUE z dnia 16 kwietnia 2014 r., Dz. Urz. UE L, 2014, nr 173, s. 149-178) jednak wciąż nie weszła w życie umowa międzyrządowa o przekazywaniu i uwspólnianiu składek na rzecz Jednolitego Funduszu Restrukturyzacji i Uporządkowanej Likwidacji, podpisana 21 maja 2014 r. przez 26 państw członkowskich Unii Europejskiej (bez Wielkiej Brytanii i Szwecji). Wspomniane wyżej rozporządzenie Parlamentu Europejskiego i Rady Unii Europejskiej z 15 lipca 2014 r. nie regulowało obowiązku przekazywania zgromadzonych na szczeblu krajowym składek do Funduszu, ponieważ taki obowiązek nie wynika z prawa unijnego (Umowa o przekazywaniu i uwspólnianiu składek na rzecz Jednolitego Funduszu Restrukturyzacji i Uporządkowanej Likwidacji, Bruksela, 21 maja 2014 r., EU/SRF, s. 7). Dlatego zgodnie z sugestią rządu niemieckiego postanowiono uregulować tę kwestię w umowie międzyrządowej. Wymaga ona jeszcze ratyfikacji przez sygnatariuszy reprezentujących co najmniej 90\% łącznej wagi głosów wszystkich państw uczestniczących w Unii Bankowej zgodnie z protokołem nr $36 \mathrm{w}$ sprawie postanowień przejściowych, załączonym do TUE i TFUE. Umowa winna jednak wejść w życie najpóźniej 1 stycznia 2016 r., tak aby umożliwić Jednolitemu Mechanizmowi Restrukturyzacji i Uporządkowanej Likwidacji uzyskanie pełnej zdolności do działania. Spośród elementów składowych trzeciego filaru brakuje jeszcze także przepisów ustanawiających wspólny mechanizm ochronny (linię kredytową).

\section{Cele i zasady działania Unii Bankowej}

Unia Bankowa winna stanowić element składowy Unii Gospodarczej i Walutowej, ale także istotne uzupełnienie rynku wewnętrznego. Jej członkami będą automatycznie wszystkie państwa należące do strefy euro. Przystapić do niej mogą także pozostałe państwa członkowskie Unii Europejskiej. Przyczyną jej utworzenia był brak skutecznej kontroli nad bankami, które podejmując ryzykowne transakcje finansowe narażały w razie bankructwa właścicieli depozytów. Gdy banki prowadziły działalność w wielu państwach, to nawet krajowe organy nadzoru nie były w stanie skutecznie sprawować nad nimi kontroli. Unia Bankowa to zatem projekt mający na celu przerwanie powiązań między problemami banków a finansami publicznymi państw, a także przywrócenie zaufania do sektora finansowego po kryzysie zadłużeniowym z lat 2010-2013. Ogromne pakiety pomocowe dla banków w czasie tegoż kryzysu obciążały bowiem dramatycznie finanse publiczne państw, co skutkowało dalszym pogłębieniem kryzysu zadłużeniowego. Unia Bankowa ma sprawować nie tylko nadzór nad instytucjami finansowymi strefy euro, ale także gwarantować, że banki będą mogły być likwidowane w sposób kontrolowany, bez szkód dla systemu finansowego państw oraz kosztów, jakie do tej pory ponosili podatnicy. Zapłacić mają za to akcjonariusze banków oraz ci, którzy poży- 
czyli im pieniądze. Chronione mają być w zasadzie tylko depozyty do 100 tys. euro. Unia Bankowa ma na celu przeniesienie z poziomu państw na szczebel Unii Europejskiej nadzoru oraz odpowiedzialności za ratowanie lub likwidację banków. Winna ona również doprowadzić do ujednolicenia odpowiedzialności za nadzór, restrukturyzację i uporządkowaną likwidację oraz finansowanie na szczeblu unijnym, a także zobowiązać banki działające w całej strefie euro do przestrzegania tych samych przepisów.

\section{IV.1. Pierwszy filar}

Jednolity Mechanizm Nadzorczy będzie się składał z EBC oraz właściwych krajowych organów nadzorczych (art. 6 ust. 1 rozporządzenia RUE z 15 października 2013 r.). EBC będzie sprawował bezpośredni nadzór nad 128 największymi bankami strefy euro (ok. 85\% aktywów bankowych w strefie euro). Pozostałe banki będą natomiast nadzorowane przez krajowe organy nadzorcze, choć ostateczną odpowiedzialność w tym zakresie będzie ponosił EBC. Zadania nadzorcze EBC nie mogą kolidować z jego uprawnieniami w dziedzinie polityki walutowej, ani też nie mogą być od nich uzależnione (art. 25 ust. 1-2 rozporządzenia RUE z 15 października 2013 r.), co pozwoli mu uniknąć potencjalnego konfliktu interesów. W ramach Jednolitego Mechanizmu Nadzorczego funkcjonować będzie Rada ds. Nadzoru, odpowiedzialna za planowanie i realizację zadań nadzorczych EBC oraz uchwalanie projektów decyzji dla Rady Prezesów EBC. W skład Rady ds. Nadzoru będą wchodzić przewodniczący, wiceprzewodniczący, 4 przedstawiciele EBC oraz po jednym reprezentancie krajowych organów nadzorczych. Wszyscy członkowie Rady ds. Nadzoru winni reprezentować interesy Unii Europejskiej (art. 26 ust. 1 rozporządzenia RUE z 15 października 2013 r.). Rada ds. Nadzoru będzie podejmować swoje decyzje co do zasady zwykłą większością głosów, przy czym w przypadku braku rozstrzygnięcia decydujący głos będzie należał do przewodniczącego (art. 26 ust. 6 rozporządzenia RUE z 15 października 2013 r.). Rada ds. Nadzoru, stanowiąc zwykłą większością głosów, powoła również spośród swoich członków komitet sterujący o mniej licznym składzie, którego celem będzie wspomaganie jej prac i przygotowywanie jej posiedzeń (art. 26 ust. 10 rozporządzenia RUE z 15 października 2013 r.). Jednolity Mechanizm Nadzorczy w pełni zacznie działać w listopadzie $2014 \mathrm{r}$.

\section{IV.2. Drugi filar}

Jednolity Mechanizm Restrukturyzacji i Uporządkowanej Likwidacji, zwany także mechanizmem upadłościowym, będzie miał na celu zagwarantowanie, aby w przyszłości potencjalne upadki instytucji kredytowych w strefie euro, w tym banków, skutkowały jedynie minimalnymi kosztami dla podatników. Realizację jednolitych zasad i jednolitej procedury upadłościowej winna zapewniać Jednolita Rada ds. Restrukturyzacji i Uporządkowanej Likwidacji wraz z Radą Unii Europejskiej, Komisją Europejską oraz krajowymi organami ds. restrukturyzacji i uporządkowanej likwidacji (art. 14 ust. 1 rozporządzenia PE i RUE z 15 lipca 2014 r.). Jednolita Rada będzie odpowiedzialna m.in. za opracowanie programu restrukturyzacji i uporządkowanej likwida- 
cji instytucji kredytowych, zawierającego m.in. decyzje o udzielaniu im pomocy finansowej. Bezzwłocznie po uchwaleniu programu Jednolita Rada winna przekazać go Komisji Europejskiej. Jeżeli Rada Unii Europejskiej, stanowiąc zwykłą większością głosów, w ciagu 24 godzin wyrazi sprzeciw wobec tego programu lub zgłosi do niego poprawki - każdorazowo na wniosek Komisji Europejskiej - nie będzie on mógł wejść w życie w wersji zaproponowanej przez Jednolitą Radę. Wtedy Jednolita Rada musi zmienić program zgodnie z oczekiwaniami Komisji Europejskiej i Rady Unii Europejskiej (art. 18 ust. 7 rozporządzenia PE i RUE z 15 lipca 2014 r.). Jednolita Rada nie będzie mogła również zmusić danego państwa wbrew jego woli do ratowania banku ze środków finansowych podatników.

Jednolita Rada będzie się składać z przewodniczącego, 4 członków oraz po 1 przedstawicielu organów nadzoru finansowego z poszczególnych państw należących do Unii Bankowej. Każdy członek Jednolitej Rady, w tym także przewodniczący, będzie miał jeden głos, ale gdy wynik głosowania będzie nierozstrzygnięty, decydujący głos należał będzie do przewodniczącego (art. 43 ust. 1-2 oraz art. 52 ust. 1 rozporządzenia PE i RUE z 15 lipca 2014 r.). Przewodniczący oraz 4 członków będą wybierani na pięcioletnią nieodnawialną kadencję i muszą oni reprezentować interesy Unii Europejskiej. Jednolita Rada będzie się zbierać na sesjach plenarnych i wykonawczych (art. 43 ust. 1-2 rozporządzenia PE i RUE z 15 lipca 2014 r.). Na sesji plenarnej co do zasady będzie podejmować decyzje zwykłą większością głosów (art. 52 ust. 1 rozporządzenia PE i RUE z 15 lipca 2014 r.). Jeżeli jednak przedmiotem głosowania będzie decyzja dotycząca udzielenia danej instytucji kredytowej pomocy finansowej w kwocie powyżej 5 mld euro lub decyzja dotycząca grupowej restrukturyzacji i uporządkowanej likwidacji obejmującej instytucje mające siedzibę w co najmniej 1 państwie strefy euro oraz w co najmniej 1 państwie nienależącym do strefy euro, wtedy Jednolita Rada będzie decydować zwykłą większością głosów swoich członków reprezentujących co najmniej 30\% wysokości składek w Jednolitym Funduszu Restrukturyzacji i Uporządkowanej Likwidacji. Każdy członek będzie miał jeden głos, ale gdy wynik będzie nierozstrzygnięty, decydujący głos będzie należał do przewodniczącego (art. 52 ust. 1 rozporządzenia PE i RUE z 15 lipca 2014 r.). Jeżeli Jednolita Rada obradować będzie na sesji wykonawczej (tzw. nieformalny Zarząd Jednolitej Rady), to decyzje tam podejmowane będą zapadać na zasadzie konsensu. Jednak gdy konsensu nie da się uzgodnić, decyzje podejmowane będą zwykłą większością głosów, przy czym w przypadku braku rozstrzygnięcia decydujący głos będzie należał do przewodniczącego. Na sesjach wykonawczych Jednolita Rada będzie podejmować m.in. decyzje dotyczące udzielenia danej instytucji kredytowej pomocy finansowej w kwocie do 5 mld euro (art. 55 ust. 1-2 rozporządzenia PE i RUE z 15 lipca 2014 r.). Jednolity Mechanizm Restrukturyzacji i Uporządkowanej Likwidacji ma być ustanowiony 1 stycznia 2015 r. i wtedy również Jednolita Rada osiagnie pełną zdolność do działania.

\section{IV.3. Trzeci filar}

Jednolity Fundusz Restrukturyzacji i Uporządkowanej Likwidacji, zwany także funduszem upadłościowym, będzie budowany stopniowo przez 8 lat, licząc od 1 stycz- 
nia 2016 r. Przed upływem tego okresu winien on dysponować co najmniej 1\% kwoty depozytów gwarantowanych wszystkich instytucji kredytowych (art. 69 ust. 1 rozporządzenia PE i RUE z 15 lipca 2014 r.), czyli jak się szacuje kwotą ok. 55 mld euro. Zgodnie z umową międzyrządową z 21 maja 2014 r. składki do Funduszu będą pobierane od banków przez krajowe organy ds. restrukturyzacji i uporządkowanej likwidacji, a następnie przekazywane do tegoż Funduszu. Początkowo środki finansowe będą gromadzone w kopertach (tzw. pulach) przypisanych do poszczególnych państw i będą mogły być przeznaczone wyłącznie na ratowanie banków mających siedzibę w danym państwie. Jednak w ciagu ośmiu lat będą one stawały się środkami wspólnymi i wtedy będą mogły być przeznaczone na restrukturyzację dowolnego banku strefy euro. W pierwszym roku uwspólnotowione zostanie 40 proc. zgromadzonych środków, w drugim roku - kolejne 20 proc., a reszta - stopniowo przez 6 kolejnych lat. Składki poszczególnych banków do Funduszu będą obliczane proporcjonalnie do kwoty ich zobowiązań oraz do stopnia ryzyka (art. 5 ust. 1 lit. a umowy międzyrządowej).

Koszty strat związanych z restrukturyzacją banków będą spoczywały głównie na ich akcjonariuszach i wierzycielach, następnie na posiadaczach depozytów powyżej 100 tys. euro, a dopiero w ostatniej kolejności (w przypadku braku wystarczających środków) na Jednolitym Funduszu Restrukturyzacji i Uporządkowanej Likwidacji (art. 15 ust. 1 rozporządzenia PE i RUE z 15 lipca 2014 r.). W okresie przejściowym brakujące środki na ratowanie banków będzie można pożyczać z rezerw znajdujących się w kopertach narodowych (art. 5 ust. 1 lit. a-b umowy międzyrządowej) albo też - na co początkowo nie chciał zgodzić się rząd niemiecki - ze środków zgromadzonych w Europejskim Mechanizmie Stabilności.

System gwarantowania depozytów obejmie wspólne gwarancje depozytów do 100 tys. euro (art. 6 ust. 1 dyrektywy PE i RUE z 16 kwietnia 2014 r.). Podstawowym zadaniem systemu gwarancji depozytów będzie ochrona deponentów przed skutkami niewypłacalności instytucji kredytowej. Banki będą miały wprawdzie możliwość wykorzystania systemu gwarantowania depozytów do finansowania środków pozwalających uniknąć ich upadku, ale będą zmuszone także do ochrony deponentów, w razie gdyby taki upadek miał miejsce. Nowe przepisy gwarantuja, że w razie upadku banku termin wypłaty depozytów winien wynosić 7 dni roboczych, czyli znacznie szybciej niż dotychczas (art. 8 ust. 1 dyrektywy PE i RUE z 16 kwietnia 2014 r.). Jednak w okresie przejściowym trwającym do 31 grudnia $2023 \mathrm{r}$. wypłaty takie dokonywane będą $\mathrm{w}$ terminie 20 dni roboczych (do 31 grudnia 2018 r.), 15 dni roboczych (1 stycznia 2019 r.31 grudnia 2020 r.) lub 10 dni roboczych (1 stycznia 2021 r.-31 grudnia 2023 r.) (art. 8 ust. 2 dyrektywy PE i RUE z 16 kwietnia 2014 r.). Z drugiej strony, w okresie przejściowym dostęp do kwot niezbędnych na pokrycie kosztów utrzymania skrócony zostanie do 5 dni od momentu złożenia wniosku przez deponenta (art. 8 ust. 4 dyrektywy PE i RUE z 16 kwietnia 2014 r.).

\section{Legitymizacja}

Ustanowienie Unii Bankowej wzmocni pozycję zarówno instytucji ponadnarodowych, jak i międzyrządowych w strefie euro, w szczególności Europejskiego Banku 
Centralnego, Parlamentu Europejskiego, Komisji Europejskiej, Trybunału Obrachunkowego oraz Rady Unii Europejskiej. Nowe kompetencje uzyskają tam również parlamenty narodowe. Wszystko to winno zapewnić legitymizację zmian ustrojowych w strefie euro. Powołanie Unii Bankowej będzie skutkowało również utworzeniem dwóch zupełnie nowych organów, czyli Rady ds. Nadzoru oraz Jednolitej Rady.

Jeśli chodzi o Europejski Bank Centralny, to uzyska on m.in. nowe uprawnienia w zakresie nadzoru ostrożnościowego nad instytucjami kredytowymi (art. 1 dyrektywy RUE z 15 października 2013 r.). Będzie on odpowiadał przed Parlamentem Europejskim i Radą Unii Europejskiej za wykonywanie swoich zadań nadzorczych. Corocznie będzie przedkładał Parlamentowi Europejskiemu, Radzie Unii Europejskiej, Komisji Europejskiej i Eurogrupie sprawozdanie z wykonania tychże zadań (art. 20 ust. 1-2 dyrektywy RUE z 15 października 2013 r.). Ponadto EBC zostanie zobowiązany do informowania Parlamentu Europejskiego i Rady Unii Europejskiej o tym, w jaki sposób przestrzega on rozdziału nowych zadań nadzorczych i swoich dotychczasowych funkcji w dziedzinie polityki pieniężnej (art. 25 ust. 2 dyrektywy RUE z 15 października 2013 r.).

Parlament Europejski otrzyma kompetencje kontrolne nad Europejskim Bankiem Centralnym, Radą ds. Nadzoru oraz Jednolitą Radą. Wspomniane wyżej porozumienie międzyinstytucjonalne między Parlamentem Europejskim a EBC przewiduje m.in., że EBC oraz przewodniczący Rady ds. Nadzoru winni przedkładać mu corocznie sprawozdania z realizacji powierzonych im zadań (pkt I.1. porozumienia). EBC ma także dostarczać właściwej komisji parlamentarnej w Parlamencie Europejskim protokoły z obrad Rady ds. Nadzoru, umożliwiające zrozumienie przebiegu debaty, wraz z opatrzonym uwagami wykazem decyzji (pkt I.4 porozumienia). Z kolei rozporządzenie Parlamentu Europejskiego i Rady Unii Europejskiej z 15 lipca 2014 r. nakłada na Jednolitą Radę m.in. obowiązek przedkładania Parlamentowi Europejskiemu, rocznych sprawozdań z wykonania powierzonych jej zadań (art. 45 ust. 2 rozporządzenia PE i RUE z 15 lipca 2014 r.). Jednolita Rada będzie miała również obowiązek udzielania ustnej lub pisemnej odpowiedzi na pytania skierowane do niej przez Parlament Europejski (art. 45 ust. 6 rozporządzenia PE i RUE z 15 lipca 2014 r.). Ponadto jej przewodniczący co najmniej raz w roku uczestniczyć będzie w przesłuchaniu organizowanym przez właściwą komisję parlamentarną Parlamentu Europejskiego w sprawie wykonania przez Jednolitą Radę zadań w zakresie restrukturyzacji i uporządkowanej likwidacji banku (art. 45 ust. 5 rozporządzenia PE i RUE z 15 lipca 2014 r.).

Co się tyczy Komisji Europejskiej, to uzyska ona m.in. uprawnienie do zatwierdzania programu restrukturyzacji i uporządkowanej likwidacji, przyjmowanego przez Jednolitą Radę. Program w wersji zaproponowanej przez Jednolitą Radę będzie mógł wejść w życie tylko wtedy, gdy zatwierdzi go Komisja Europejska. Jeżeli jednak sprzeciwi się ona programowi lub zaproponuje w nim zmiany, każdorazowo zaakceptowane przez Radę Unii Europejskiej, to wówczas Jednolita Rada będzie musiała program zmienić zgodnie z oczekiwaniami Komisji Europejskiej (art. 18 ust. 7 rozporządzenia PE i RUE z 15 lipca 2014 r.). Ponadto Jednolita Rada będzie miała obowiązek przedkładania Komisji Europejskiej rocznych sprawozdań z wykonania powierzonych jej zadań (art. 45 ust. 2 rozporządzenia PE i RUE z 15 lipca 2014 r.).

Nowe kompetencje Trybunału Obrachunkowego w strefie euro będą polegały m.in. na badaniu wspomnianych wyżej zadań nadzorczych Europejskiego Banku Centralnego 
(art. 20 ust. 6 rozporządzenia RUE z 15 października 2013 r.) oraz wstępnego sprawozdania finansowego Jednolitej Rady wraz ze sprawozdaniem z zarządzania budżetem i finansami w danym roku budżetowym. Trybunał Obrachunkowy będzie także przyjmował ostateczne sprawozdanie finansowe Jednolitej Rady za poprzedni rok budżetowy oraz sporządzał na tej podstawie własny raport (art. 63 ust. 2, 5, art. 92 ust. 4 rozporządzenia PE i RUE z 15 lipca 2014 r.). Jednym z najważniejszych zadań będzie sprawowanie kontroli nad beneficjentami, wykonawcami i podwykonawcami, którzy otrzymali środki finansowe od Jednolitej Rady (art. 66 ust. 2 rozporządzenia PE i RUE z 15 lipca 2014 r.). Ponadto Jednolita Rada będzie miała obowiązek przedkładania Trybunałowi Obrachunkowemu rocznych sprawozdań z wykonania powierzonych jej zadań (art. 45 ust. 2 rozporządzenia PE i RUE z 15 lipca 2014 r.).

Nowe uprawnienia Rady Unii Europejskiej będą się sprowadzały m.in. do sprawowania wraz z Parlamentem Europejskim nadzoru nad EBC w zakresie wykonywanych przez tę instytucję zadań nadzorczych (art. 20 ust. 1 rozporządzenia RUE z 15 października 2013 r.). Rada Unii Europejskiej wraz z Komisją Europejska, Jednolitą Radą oraz krajowymi organami ds. restrukturyzacji i uporządkowanej likwidacji winna zapewniać realizację jednolitych zasad i jednolitej procedury upadłościowej, w tym m.in. uczestniczyć w procedurze uchwalania programów naprawczych przyjmowanych przez Jednolita Radę (art. 14 ust. 1 oraz art. 18 ust. 7-8 rozporządzenia PE i RUE z 15 lipca 2014 r.).

Parlamenty narodowe uczestniczących państw członkowskich uzyskają niewielkie, ale dość istotne uprawnienia w Unii Bankowej. Będą one otrzymywały coroczne sprawozdania EBC i Jednolitej Rady z realizacji powierzonych im zadań oraz będą mogły kierować do tychże podmiotów uzasadnione uwagi na temat wspomnianych sprawozdań (art. 21 ust. 1 rozporządzenia RUE z 15 października 2013 r. oraz art. 45 ust. 2 rozporządzenia PE i RUE z 15 lipca 2014 r.). Parlamenty narodowe uczestniczących państw członkowskich będą mogły także zwracać się do EBC i Jednolitej Rady o udzielenie pisemnej odpowiedzi na wszelkie uwagi i zapytania dotyczące pełnionych przez nie funkcji (art. 21 ust. 1-2 rozporządzenia RUE z 15 października 2013 r. oraz art. 45 ust. 2 rozporządzenia PE i RUE z 15 lipca 2014 r.).

\section{Konkluzje}

Najważniejszym problemem, z jakim przyjdzie się zmierzyć Unii Bankowej w razie wybuchu nowego kryzysu finansowego, będzie zbyt mała pula dostępnych środków. Według niektórych szacunków kryzys zadłużeniowy strefy euro z lat 2010-2013 pochłonął ok. 1,6 biliona euro, zaś instytucje finansowe państw nim dotkniętych mogą mieć w swoich księgach nawet ok. 1 biliona euro długów trudnych do odzyskania. Dlatego 500 mld euro, jakimi dysponuje Europejski Mechanizm Stabilności, oraz 55 mld euro z Jednolitego Funduszu Restrukturyzacji i Uporządkowanej Likwidacji to niewiele. Według niektórych opinii kwota 55 mld euro może bowiem wystarczyć jedynie na uratowanie dwóch średniej wielkości banków (Popławski, 2014; Bielecki, 2014; Legrain, 2014). Argumenty te osłabia jednak fakt, że, jak wspomniano wyżej, wydatki na restrukturyzację banków będą pochodziły głównie od ich akcjonariuszy i wierzycieli, następnie od posiadaczy depozytów powyżej 100 tys. euro, a dopiero w ostatniej kolej- 
ności od Jednolitego Funduszu Restrukturyzacji i Uporządkowanej Likwidacji. Warto wszakże zauważyć, że decyzje podejmowane przez Jednolity Mechanizm Restrukturyzacji i Uporządkowanej Likwidacji mogą rzutować na państwa nienależące do strefy euro. Chodzi m.in. o sytuację, gdy w przypadku grupowej restrukturyzacji i likwidacji banków państwo macierzyste danego banku oraz państwo spoza strefy euro, posiadające jego filię, nie będą w stanie się porozumieć, to o rozstrzygnięciu sporu zadecyduje Europejski Urząd Nadzoru Bankowego.

Ustrojowe rozwiązania przyjęte dla Unii Bankowej zapewniają zwłaszcza Niemcom, ale także Francji, znaczący wpływ na jej funkcjonowanie. Pierwotnie Unia Bankowa miała mieć charakter ponadnarodowy, jednak Niemcy wraz z Francją i kilkoma innymi państwami nie zgodziły się na projekt Komisji Europejskiej, co doprowadziło do osłabienia uprawnień tej nowej struktury w Unii Gospodarczej i Walutowej. Ostatecznie postanowiono, że Unia Bankowa będzie międzyrządową strukturą trzyfilarową i winna się opierać na dwóch różnych porządkach prawnych: prawie unijnym oraz umowie międzyrządowej. To właśnie głównie pod wpływem rządu niemieckiego zdecydowano się na określenie zasad funkcjonowania Jednolitego Funduszu Restrukturyzacji i Uporządkowanej Likwidacji w umowie międzyrządowej, a nie w akcie prawa pochodnego. Rząd niemiecki argumentował bowiem w czasie negocjacji, że prawo unijne nie daje wystarczającej podstawy prawnej do utworzenia takiego Funduszu, co grozi zakwestionowaniem go w przyszłości przez Federalny Trybunał Konstytucyjny w Niemczech. Pod naciskiem Niemiec opracowane zostały również warunki ustanowienia systemu gwarancji depozytów. Strony zgodziły się jedynie na przepisy harmonizujące działalność krajowych funduszy gwarancyjnych, a nie na ich unifikację, czyli powołanie wspólnego funduszu gwarancyjnego dla całej strefy euro.

Również szczegółowe uregulowania zasad funkcjonowania Unii Bankowej zostały uzgodnione pod dużym wpływem rządu niemieckiego. Niemcom udało się obwarować proces restrukturyzacji banków państw strefy euro licznymi zabezpieczeniami, które wzmacniają ich pozycję w procesie podejmowania decyzji, ale także komplikują funkcjonowanie Unii Bankowej. Rezultatem jest m.in. taki system głosowań w Jednolitej Radzie, który ułatwi Niemcom czy Francji tworzenie koalicji blokujących przy restrukturyzacjach wymagających powyżej 5 mld euro pomocy lub obejmujących instytucje mające siedzibę $w$ co najmniej jednym państwie strefy euro oraz w co najmniej jednym państwie nienależącym do strefy euro (tzw. grupowa restrukturyzacja). Albowiem jak wspomniano wyżej Jednolita Rada, zbierająca się na sesji wykonawczej, ma decydować w trybie zwykłej większości głosów w sprawie działań z niedużym wsparciem finansowym, natomiast przy decyzjach przekraczających 5 mld euro pomocy lub dotyczących grupowej restrukturyzacji Jednolita Rada, obradująca na sesji plenarnej, będzie decydować zwykłą większością głosów swoich członków reprezentujących co najmniej 30\% wysokości składek w Jednolitym Funduszu Restrukturyzacji i Uporządkowanej Likwidacji. Ponieważ Niemcy będą miały największy udział w Funduszu, będą też mieć decydujący głos we wszystkich najważniejszych procesach restrukturyzacji i uporządkowanej likwidacji, a w ślad za tym będą mogły wpływać na kierunek reform w państwach ogarniętych kryzysem finansowym.

Proces konstytuowania Unii Bankowej ukazał słabą wobec rządów państw członkowskich strefy euro pozycję Komisji Europejskiej i Parlamentu Europejskiego. Z dru- 
giej strony, spośród rządów państw należących do Unii Walutowej największy wpływ na przebieg negocjacji miał rząd niemiecki, natomiast osłabieniu uległa pozycja Francji. Można wręcz zaryzykować tezę, że Niemcy zyskały ekonomicznie i politycznie na przebiegu kryzysu zadłużeniowego strefy euro oraz na reformie ustrojowej strefy euro. Z kryzysu wyszły w zasadzie bez szwanku, zaś po przyjęciu raportu Van Rompuy’a - jako mapy drogowej wskazującej drogę wyjścia z tegoż kryzysu - narzuciły w dużej mierze sposób przeprowadzenia reformy ustrojowej strefy euro. W związku z tym można postawić drugą tezę, że Niemcy, co najmniej doraźnie, wyrosły na jedynego obecnie lidera Unii Europejskiej.

\section{Bibliografia}

\section{I. Źródła}

Dyrektywa Parlamentu Europejskiego i Rady z dnia 15 maja 2014 r. ustanawiajacca ramy na potrzeby prowadzenia działań naprawczych oraz restrukturyzacji i uporzqdkowanej likwidacji w odniesieniu do instytucji kredytowych i firm inwestycyjnych oraz zmieniajaca dyrektywę Rady nr 82/891 EWG i dyrektywy Parlamentu Europejskiego i Rady nr 2001/24/WE, nr 2002/47/WE, nr 2004/25/WE, nr 2005/56/WE, nr 2007/36/WE, nr 2011/35/UE, nr 2012/30/UE i $n r$ 2013/36/EU oraz rozporzqdzenia Parlamentu Europejskiego i Rady (UE) nr 1093/2010 i (UE) nr 648/2012, Dziennik Urzędowy Unii Europejskiej L, 2014, nr 173.

Dyrektywa Parlamentu Europejskiego i Rady z dnia 16 kwietnia 2014 r. w sprawie systemów gwarancji depozytów, Dziennik Urzędowy Unii Europejskiej L, 2014, nr 173.

Dyrektywa Parlamentu Europejskiego i Rady z dnia 26 czerwca 2013 r. w sprawie warunków dopuszczenia instytucji kredytowych do działalności oraz nadzoru ostrożnościowego nad instytucjami kredytowymi i firmami inwestycyjnymi, zmieniajaca dyrektywe 2002/87/WE $i$ uchylajaca dyrektywy 2006/48/WE oraz 2006/49/WE, Dziennik Urzędowy Unii Europejskiej L, 2013, nr 176.

Komisja Europejska, Komunikat Komisji do Parlamentu Europejskiego i Rady, Plan działania na rzecz unii bankowej, Bruksela, 12 września 2012 r., COM(2012) 510 wersja ostateczna.

Komisja Europejska, Komunikat Komisji do Parlamentu Europejskiego i Rady, Plan działania na rzecz pogłębionej i rzeczywistej unii gospodarczej $i$ walutowej. Otwarcie debaty europejskiej, Bruksela, 30 listopada 2012 r., $\operatorname{COM(2012)~} 777$.

Komisja Europejska, Notatka prasowa - Unia Bankowa: przywracamy stabilność finansowa w strefie euro, Bruksela, 15 kwietnia 2014 r.

Porozumienie międzyinstytucjonalne między Parlamentem Europejskim a Europejskim Bankiem Centralnym $w$ sprawie praktycznych zasad egzekwowania demokratycznej odpowiedzialności i sprawowania nadzoru nad wykonywaniem zadań powierzonych EBC w ramach jednolitego mechanizmu nadzorczego, Dziennik Urzędowy Unii Europejskiej L, 2013, nr 320.

Posiedzenie Rady Europejskiej w dniach 13-14 grudnia 2012 r., Konkluzje, Bruksela, 14 grudnia 2012 r., EUCO 205/12.

Posiedzenie Rady Europejskiej w dniach 14-15 marca 2013 r., Konkluzje, Bruksela, 14 marca 2013 r., EUCO 23/13.

Posiedzenie Rady Europejskiej w dniach 20-21 marca 2014 r., Konkluzje, Bruksela, 21 marca 2014 r., EUCO 7/1/14, REV 1. 
Posiedzenie Rady Europejskiej w dniach 27-28 czerwca 2013 r., Konkluzje, Bruksela, 28 czerwca 2013 r., EUCO 104/2/13, REV 2.

Rada Europejska, Przewodniczący, W kierunku faktycznej Unii Gospodarczej $i$ Walutowej [Sprawozdanie końcowe], Bruksela, 5 grudnia 2012 r.

Rada Europejska, Przewodniczący, W kierunku faktycznej Unii Gospodarczej $i$ Walutowej [Sprawozdanie końcowe], Bruksela, 5 grudnia 2012 r.

Rozporządzenie Europejskiego Banku Centralnego z dnia 16 kwietnia 2014 r. ustanawiajace ramy wspótpracy pomiędzy Europejskim Bankiem Centralnym a właściwymi organami krajowymi w ramach Jednolitego Mechanizmu Nadzorczego (Rozporządzenie ramowe w sprawie jednolitego mechanizmu nadzorczego), EBC 2014/17.

Rozporządzenie Parlamentu Europejskiego i Rady z dnia 26 czerwca 2013 r. w sprawie wymogów ostrożnościowych dla instytucji kredytowych i firm inwestycyjnych, zmieniajace rozporzadzenie (UE) nr 648/2012, Dziennik Urzędowy Unii Europejskiej L, 2013, nr 176.

Rozporządzenie Parlamentu Europejskiego i Rady z dnia 22 października 2013 r., zmieniajace rozporzadzenie (UE) nr 1093/2010 w sprawie ustanowienia Europejskiego Urzędu Nadzoru (Europejskiego Urzędu Nadzoru Bankowego) w odniesieniu do powierzenia Europejskiemu Bankowi Centralnemu szczególnych zadań zgodnie z rozporzq̨dzeniem Rady UE nr 1024/2013, Dziennik Urzędowy Unii Europejskiej L, 2013, nr 287.

Rozporządzenie Parlamentu Europejskiejgo i Rady z dnia 15 lipca 2014 r. ustanawiajace jednolite zasady oraz jednolita procedurę restrukturyzacji i uporzadkowanej likwidacji instytucji kredytowych i niektórych firm inwestycyjnych w ramach jednolitego mechanizmu restrukturyzacji i uporzqdkowanej likwidacji oraz jednolitego funduszu restrukturyzacji i uporzqdkowanej likwidacji oraz zmieniajace rozporzqdzenie (UE) nr 1093/2010, Dziennik Urzędowy Unii Europejskiej L, 2014, nr 225.

Rozporządzenie Rady z dnia 15 października 2013 r. powierzające Europejskiemu Bankowi Centralnemu szczególne zadania w odniesieniu do polityki zwiqzanej z nadzorem ostrożnościowym nad instytucjami kredytowymi, Dziennik Urzędowy Unii Europejskiej L, 2013, nr 287.

Traktat z Lizbony (dalej - Traktat z Lizbony), zmieniajacy traktat o Unii Europejskiej i traktat ustanawiajacy Wspólnotę Europejska, podpisany w Lizbonie 13 grudnia 2007 r. (teksty skonsolidowane), Dziennik Urzędowy Unii Europejskiej C, 2008, nr 115.

Umowa o przekazywaniu i uwspólnianiu składek na rzecz Jednolitego Funduszu Restrukturyzacji i Uporzqdkowanej Likwidacji, Bruksela, 21 maja 2014 r., EU/SRF.

\section{Artykuly}

Bielecki T. (2014), Bankowe spory Europy, czyli trzy etapy unii bankowej, „Gazeta Wyborcza”, 17 lutego.

Legrain P. (2014), Fiskalny kolonializm eurostrefy, „The New York Times”, 27 kwietnia (przedruk w interia.pl, s. 1).

Popławski K. (2014), Kształt unii bankowej potwierdza uprzywilejowana pozycję Berlina w strefie euro, Komentarz OSW, 10 stycznia.

\section{Streszczenie}

W artykule zaprezentowane zostały geneza, proces legislacyjny, podstawy prawne, cele i zasady działania Unii Bankowej jako nowej struktury organizacyjnej Unii Gospodarczej i Walutowej. Omówione zostały również wynikające z reformy ustrojowej nowe uprawnienia instytucji po- 
nadnarodowych i międzyrządowych Unii Europejskiej (Europejskiego Banku Centralnego, Parlamentu Europejskiego, Komisji Europejskiej, Trybunału Obrachunkowego i Rady Unii Europejskiej), a także parlamentów narodowych w strefie euro.

Ustanowienie Unii Bankowej, która uzyska pełną zdolność do działania od 1 stycznia 2016 r., rodzi już dzisiaj wiele uzasadnionych wątpliwości. Najważniejszą z nich jest obawa, że pula środków finansowych, jakimi będzie ona dysponować, będzie zbyt mała w razie wybuchu nowego kryzysu finansowego w strefie euro. Argumenty te w pewnym stopniu osłabia fakt, że wydatki na restrukturyzację banków będą pochodziły głównie od ich akcjonariuszy i wierzycieli, następnie od posiadaczy depozytów powyżej 100 tys. euro, a dopiero w ostatniej kolejności od Jednolitego Funduszu Restrukturyzacji i Uporządkowanej Likwidacji. Kolejną wątpliwość budzą ustrojowe rozwiązania przyjęte dla Unii Bankowej, ponieważ zapewniają one zwłaszcza Niemcom, ale także Francji, znaczący wpływ na jej funkcjonowanie. Niemcom udało się obwarować proces restrukturyzacji banków państw strefy euro licznymi zabezpieczeniami, które wzmacniają ich pozycję w procesie podejmowania decyzji (np. w Jednolitej Radzie ds. Restrukturyzacji i Uporządkowanej Likwidacji), ale także komplikują funkcjonowanie Unii Bankowej. Ponieważ Niemcy będą miały największy udział w Funduszu Restrukturyzacji i Uporządkowanej Likwidacji, będą też mieć decydujący głos we wszystkich najważniejszych procesach upadłościowych, a w ślad za tym będą mogły wpływać na kierunek reform w państwach ogarniętych kryzysem finansowym. Można wręcz zaryzykować tezę, że Niemcy zyskały ekonomicznie i politycznie na przebiegu kryzysu zadłużeniowego strefy euro oraz na reformie ustrojowej strefy euro. Z kryzysu wyszły w zasadzie bez szwanku, a następnie w dużej mierze narzuciły sposób przeprowadzenia reformy ustrojowej strefy euro. Co najmniej doraźnie Niemcy wyrosły na jedynego obecnie lidera Unii Europejskiej.

Slowa kluczowe: Unia Europejska, kryzys strefy euro, unia bankowa

\section{The process of establishing Banking Union. Origins, legal foundations, objectives and operating principles}

\section{Summary}

The paper presents the origins, legislative process, legal foundations, objectives and operating principles of the Banking Union as a new organisational structure of Economic and Monetary Union. The paper also discusses new powers vested by virtue of the political reform to supranational and intergovernmental institutions of the European Union (the European Central Bank, the European Parliament, the European Commission, the Court of Auditors and the Council of the European Union) as well as to the national parliaments of euro zone countries.

The establishment of Banking Union, which will become fully operational on 1 January, 2016, raises numerous justifiable concerns. The main one is that the resources at its disposal will be too limited when a new financial crunch breaks out in the euro zone. This concern is somewhat weakened by the fact that the outlay on the restructurisation of banks will mainly be borne by their shareholders and creditors, followed by the holders of deposits in excess of EUR 100,000 and only eventually by the single resolution mechanism (SRM). Another concern is raised by the solutions adopted for Banking Union, which give significant influence on its operation primarily to Germany, and also to France. Germany succeeded in conditioning the process of restructuring euro area banks on numerous safeguards that strengthen Germany's position in the decision-making process (e.g. in the Single Resolution Board) but also make the operation of Banking Union more complicated. Since Germany is going to have the greatest share in the 
SRM, it will also have a decisive say in all the most important bankruptcy processes, thereby influencing the direction of reforms in countries suffering from a financial crisis. One can venture to say that Germany has benefited economically and politically from the debt crisis of the euro zone and its reform. Germany has emerged from the crisis practically unscathed, and to a large extent imposed its own approach to the reform in the euro zone. Germany has emerged as the only European Union leader, at least for now.

Key words: European Union - euro zone crisis - banking union 
